После проведения корректировки - 0,99 руб. активов. Финансовая устойчивость вследствие корректировки отложенными налоговыми активами и обязательствами увеличилась на 0, 25 руб. активов.

Таблица 3

Динамика коэффиичента зависимости ПАО «Газпром» за 2014 г. - 2016 г.

\begin{tabular}{|c|c|c|c|}
\hline Период & $\begin{array}{c}\text { КФ финансовой } \\
\text { зав-сти }\end{array}$ & $\begin{array}{c}\text { Скоррек-ванный КФ } \\
\text { финансовой зав-сти }\end{array}$ & $\begin{array}{c}\text { Динамика } \\
\text { Кчнансовой зав-сти }\end{array}$ \\
\hline за 2014 г. & 0,74 & 0,99 & 0,25 \\
\hline за 2015 г. & 0,72 & 0,74 & 0,02 \\
\hline за 2016 г. & 0,75 & 0,78 & 0,03 \\
\hline
\end{tabular}

По динамике видно, что после корректировки коэффициента устойчивости показатели возрастают. При данном методе отложенные налоги влияют на величину обязательства по налогу на прибыль, увеличивая или уменьшая его величину, тем самым оказывают влияние на финансовый результат:

1. Отражая ОНА, увеличивается обязательство по налогу на прибыль и соответственно уменьшается финансовый результат.

2. Отражая ОНО, уменьшается обязательство по налогу на прибыль и соответственно увеличивается финансовый результат.

Подведя итог, можно сделать вывод, что первый способ больше показывает влияние отложенных налогов на источники формирования капитала, а второй способ на различные коэффициенты задолженности. При оценке существенности влияния отложенных налогов на показатель нераспределенной прибыли необходимо учитывать взаимоисключающее влияние отложенных налоговых активов и отложенных налоговых обязательств.

Отложенные налоги окажут существенное влияние на показатель нераспределенной прибыли только при существенной величине либо отложенного налогового актива, либо отложенного налогового обязательства. При сравнительно одинаковых суммах отложенных налоговых активов и отложенных налоговых обязательств их совокупное влияние будет несущественным.

$$
* * *
$$

1. Приказ Минфина России от 19.11.2002 N 114н (ред. от 06.04.2015) "Об утверждении Положения по бухгалтерскому учету "Учет расчетов по налогу на прибыль организаций" ПБУ 18/02" (Зарегистрировано в Минюсте России 31.12.2002 N 4090)

2. Международный стандарт финансовой отчетности (IAS) 12 "Налоги на прибыль" (введен в действие на территории Российской Федерации Приказом Минфина России от 25.11.2011 N 160н) (ред. от 26.08.2015) (с изм. и доп., вступ. в силу с 01.01.2017)

3. Отчетность ПАО «Газпром» за 2014 г. - 2016 г.

\title{
Су Цзин \\ Проблемы формирования заработной платы как фактора социального благополучия: опыт России и Китая
}

Владивостокский государственный университет экономики и сервиса (Россия, Владивосток)

doi:10.18411/spc-22-11-2017-27

idsp: 000001:spc-22-11-2017-27

\section{Аннотация}

Статья посвящена важной социально-экономической теме - формированию заработной платы, являющейся основным источником дохода для населения многих стран, включая Россию и Китай. Цель статьи заключается в рассмотрении проблем формирования заработной платы как фактора социального благополучия на опыте России и Китая. Автор затрагивает и теоретические, и практические аспекты этих 
проблем, изучая их в сравнении ситуаций в России и Китае. Автор делает вывод о схожести проблем, связанных с формированием заработной платы в обеих странах.

Ключевые слова: Заработная плата, уровень дохода населения, социальное благополучие, качество жизни, уровень оплаты труда, дифференциация заработной платы, миграция, проблемы формирования заработной платы.

Одним из важнейших источников доходов современного общества является заработная плата, составляя в развитых странах более половины доходов населения. В России также основная доля денежных доходов также приходится на заработную плату. Исследование рынка труда, уровня и динамики заработной платы, ее дифференциации являются одним из составляющих при определении благосостояния российского общества. Представления о заработной плате связаны с объективно требуемым для воспроизводства рабочей силы и эффективного функционирования производства объема жизненных средств, которые работник получает в стоимостной форме за свой труд, соответствующим достигнутому уровню развития производственных сил общества и воплощающимся в исторически сложившемся наборе потребительских благ и услуг, необходимых работнику и членам его семьи. Рассматривать заработную плату следует не только как экономическую категорию, но и как нравственную, так как она обеспечивает человеку определенный статус. О социально-экономических последствиях процессов движения заработной платы и цен на товары и услуги можно судить, сопоставив уровень и динамику заработной платы с уровнем и динамикой прожиточного минимума трудоспособных граждан[1].

Таким образом, необходимость исследований уровня и динамики оплаты труда в любой стране обусловлена тем, что:

- оплата труда является одним из важнейших показателей оценки материального благосостояния населения, влияющего на его уровень жизни;

- дифференциация по оплате труда служит одним из факторов социальной стратификации населения;

- оплата труда, в том числе и заработная плата - это основная составляющая затрат предприятий и организаций на рабочую силу.

Заработная плата должна изучаться с двух сторон: с одной стороны, как вклад основной источник доходов населения, с другой стороны, как источник формирования затрат в экономике и, соответственно, как фактор, влияющий на структуру себестоимости национального производства. Использование новых современных методов и механизмов начисления и выплаты заработной платы служат росту качества жизни народа и достижениюсоциальной стабильности, повышению эффективностииспользования рабочей силы, увеличению добавленной стоимости в стране[2].

По мере развития рыночных отношений в любом обществе возникает целый ряд проблем, связанных с реальным уровнем заработной платы, ее динамикой (по сравнению с динамикой создаваемого общественного продукта) и ее дифференциацией. Первой проблемойявляется достижение такого уровня заработной платы, при котором становится возможным расширенное воспроизводство рабочей силы и общественного продукта. Как показывает опыт многих стран, в том числе России и Китая, в настоящее время уровень оплаты труда основных производственных работников недостаточен для нормального воспроизводства рабочей силы. Среднемесячная заработная плата в России в 2016 году составила 36200 руб., или около 600 долл. Это примерно в 5-6 раз меньше уровня оплаты труда в США, в 4,6 раза меньше, чем в Австралии, в 3,2 раза меньше, чем в Японии, в 1,4 меньше, чем в Венгрии. В Китае среднегодовая зарплата 2016 года составила 62029 юаней, или около 10340 долл. Это в 3,7 раза меньше, чем в 
США, в 2,8 раза меньше, чем в Республике Корея и в 1,9 раза меньше, чем во Франции. В номинальном выражении один средний занятый в Китае получает в 1,4 раза больше, чем средний занятый в России [3].

Мировой опыт подтверждает, что при низкой заработной плате бизнес не вкладывает средства в научно-технические преобразования, так как внедрение научнотехнического прогресса возможно тогда, когда затраты на это ниже сэкономленной заработной платы. В частности, в России служащие государственных учреждений и предприятий, т.е. врачи, учителя, специалисты («бюджетники») составляют достаточно высокий удельный вес в рабочей силе, однако, их заработная плата, как правило, на 20$40 \%$ ниже средней заработной платы по стране[4]. В развивающемся Китае также существуют социально уязвимые слои населения, которые страдают от заниженного уровня дохода: это, в первую очередь, мигранты, заработная плата которых составляет только $36 \%$ от зарплаты остальных рабочих[5].

С точки зрения качества жизни и Россия, и Китай стремятся к постиндустриальной экономике, поэтому рассматривают человеческие ресурсыи накапливаемый на их основе человеческий капитал как ключевой фактор развития, приоритетная роль которого обусловлена инновационной направленностью и увеличением доли наукоемкойпродукции в структуре экспорта [6]. Политика в отношение заработной платы в краткосрочной перспективе направлена на рост занятости, стимулирование предпринимательства, в том числе малого, повышение грамотности и профессионального уровня человеческих ресурсов, в долгосрочной перспективе - на улучшение структуры экономики, повышение инновационной составляющей, а также совершенствование регулирования демографического развития[7].

Помимо уровня заработной платы, важной проблемой является дифференциация оплаты труда. С теоретических позиций дифференциация оплаты труда - объективное явление, так как отражает специфику труда в рыночных условиях.Но именно эта проблема может существенно поколебать социальную обстановку в стране. На степень дифференциации влияют много факторов: соотношение спроса и предложения рабочей силы, уровень развития региональной экономики, дополнительный доход, а том числе от предпринимательской деятельности, рост стоимости труда высококвалифицированных работников и т.д. [8].

И в России, и в Китае дифференциация оплаты труда связана, как правило, с отраслевыми и региональными диспропорциями развития. Например, в России доходы населения, занятых в нефетгазовойотрасли и финансовом секторе,могут в разы превышать доходы в промышленности или государственном секторе. Сравнительный анализ средней заработной платы в регионах России показывает тенденцию к увеличению разрыва между центром и регионами. Особенно это стало заметно на фоне кризисных явлений в экономике, который не только снизил доходы, нои повысил уровень безработицы в регионах. Уровень зарплаты в Центральном федеральном округе в 2016 г. составил 43780 руб., а в среднем по стране - 36200 руб.Средняя заработная плата в Москве составляет 69000руб.,в Санкт-Петербурге - 50000руб., Приморском крае - 33990 руб., Сибирском федеральном округе - 30030руб., Ленинградской области - 28050 руб., Республике Татарстан - 27060руб., Смоленской области - 20020 руб. [9].

В Китае можно видеть похожую картину. Из-за неравномерного развития территорий в ходе экономических реформ, доминирования ряда отраслей наблюдается существенная дифференциация заработной платы. Больше всего китайские работники получают в наукоемких инновационных отраслях - 112042 юаней в год, что на 80,6\% больше средней зарплаты по стране, в сфере финансов - 114777 юаней в год, что на $85,0 \%$ больше среднего уровня. Меньше всего традиционно достается работникам 
сельского хозяйства, которые получают 31947 юаней в год, что на 48,5\% меньше средней зарплаты, и занятым в службах снабжения и строительстве - 43528 юаней, что на 29,8\% меньше среднего уровня. Сравнение по регионам Китая показывает, что больше всего получают дохода работники крупнейших городов Пекина - 111390 юаней в год, Шанхая - 109174 юаней и Тяньцзиня - 80090 юаней. Меньше всех традиционно получают жители провинции Хенань (центральная часть Китая) - 45403 юаней в год и провинции Хэйлунцзян (северо-восток Китая) - 48881 юаней в год [10].

Стоит отметить еще одну важную проблему, характерную для российского и китайского рынков труда - миграцию. Обе страны испытывают внешнее и внутреннее миграционное давление. В России в большей степени ощущается внешняя миграция [11], а в Китае - внутренняя миграция [5]. Специалисты говорят о миграции как о необходимом элементе регионального и национального развития [12], но вместе с тем, миграция способствует появлению целого ряда социальных проблем, которые влияют на уровень занятости, на уровень заработной платы, степень дифференциации оплаты труда и на условия жизни населения. Больше всего негативные последствия миграции ощущаются в Китае с его многочисленным населением. За 1990-2016 годы Китай переживает существенный рост внутренней миграции: среднегодовая численность мигрирующего населения составляет около 250 млн. чел. в год, что в 1,7 раза больше всего населения России. При этом, численность населения городов, куда стремятся мигрант, увеличилась за последние 35 лет на 700 млн. чел. [10].

Таким образом, России и Китае предстоит решить много проблем, связанных с уровнем заработной платы и качеством жизни своего населения. Наиболее насущными вопросами в этом плане являются улучшение условий для равномерного развития отраслей и территорий, устранение негативных последствий миграции, предотвращение дальнейшего углубления дифференциации уровней доходов населения.

1. Абдулгамидова Д.А. Заработная плата как ключевой аспект современного рынка труда // Теория и практика общественного развития. - 2015. - № 4. - С. 73-75.

2. Организация и регулирование оплаты труда: учеб. пособие для студентов вузов / [авт.: М. Е. Смирнова, М. Е. Сорокина, А. А. Федченко, П. Э. Шлендер]. - М.: Вузовский учебник, 2012. - 301 с.

3. Organization for Economic Cooperation and Development [Electronic Resource] // OECD Site. - URL: http://www.oecd.org/.

4. Гишкаева Л.Л. Уровень и динамика заработной платы в России // Молодой ученый. - 2013. - №3. C. 207-209.

5. Бао Г. Основные социально-экономические проблемы рабочих-мигрантов современного Китая // В сборнике: Научные исследования и разработки студентов сборник материалов Международной студенческой научно-практической конференции. Череповец: Изд-во ООО «Центр научного сотрудничества «Интерактив плюс». - 2016. - С. 103-106.

6. Красова Е.В., Ян С. Современные тенденции формирования человеческих ресурсов как фактора устойчивого развития экономики Китая // Экономические и социальные перемены: факты, тенденции, прогноз. - 2016. - № 3 (45). - С. 205-220.

7. Осипов В.А. Ключевые факторы развития и современная структура предпринимательства в России // Экономика и предпринимательство. - 2017. - № 3-1 (80-1). - С. 541-544.

8. Токаева С.К., Токаева М.Э. Проблемы формирования заработной платы в современных условиях // Международный научный альманах. - 2016. - № 4 (4). - С. 380-388.

9. Затраты на рабочую силу и заработная плата [Электронный ресурс] // Официальный сайт Росстата. Режим доступа: wps/wcm/connect/rosstat_main/rosstat/ru/statistics/wages/labour_costs/.

10. Статистический ежегодник Китая 2016 г. [Электронный ресурс] // Официальный сайт Национального статистического бюро Китая. - Режим доступа: http://www.stats.gov.cn/tjsj/ndsj/2016/indexeh.htm.

11. Горбенкова Е.В. Привлечение иностранной рабочей силы на Дальний Восток России: подходы к проблеме и предпосылки развития // Проблемы современной экономики. - 2012. - № 1. - С. 285-288.

12. Красова Е.В. Иностранная рабочая сила как элемент воспроизводства трудовых ресурсов региона // Фундаментальные исследования. - 2015. - № 2-21. - С. 4722-4726. 